\title{
The Economics of Ethanol, Agriculture and Food
}

\author{
Douglas Auld ${ }^{1}$ \\ ${ }^{1}$ Department of Economics and Finance, University of Guelph, Guelph, Canada \\ Correspondence: Douglas Auld, Department of Economics and Finance, University of Guelph, Guelph, Ontario \\ N1G 2W1, Canada. E-mail: dauld@uoguelph.ca
}

Received: March 29, 2012 Accepted: July 16, 2012 Online Published: July 31, 2012

doi:10.5539/jsd.v5n8p136 URL: http://dx.doi.org/10.5539/jsd.v5n8p136

\begin{abstract}
The global expansion of the production and consumption of bio-fuels has had a pronounced and widespread impact on related factor and product markets. This is most notable in the case of ethanol. The use of corn to produce bio-fuel for blending with gasoline in many countries has contributed to the recent increases in the price of corn and food. The diversion of corn from food and animal feed to fuel, and the conversion of crop land to produce corn-for-fuel, has led to supply and price pressure on other cereal and feed crops. This has led to diminished and more costly supplies of food for global food aid programs.
\end{abstract}

Keywords: bio-fuels, ethanol, agriculture, food prices, factor allocation, redistribution

\section{Introduction}

Bio-fuel production and consumption is a global, multi-billion dollar business supported by billions of dollars in government subsidies in Australia, Brazil, Canada, China, Europe, India and the United States. The increased demand for and production of bio-fuels is having an impact on the markets that provide the inputs for those bio-fuels leading to a reallocation of labor, capital and technology resources. It is also affecting the price of food, the use of land and water and a wide range of final goods that utilize food and non-food crops as inputs. Nowhere is this more evident than in the case of the production and consumption of ethanol around the globe. The drive to expand ethanol production and consumption has become not only an economic issue but a national and global political issue as well. This is the focus of our paper.

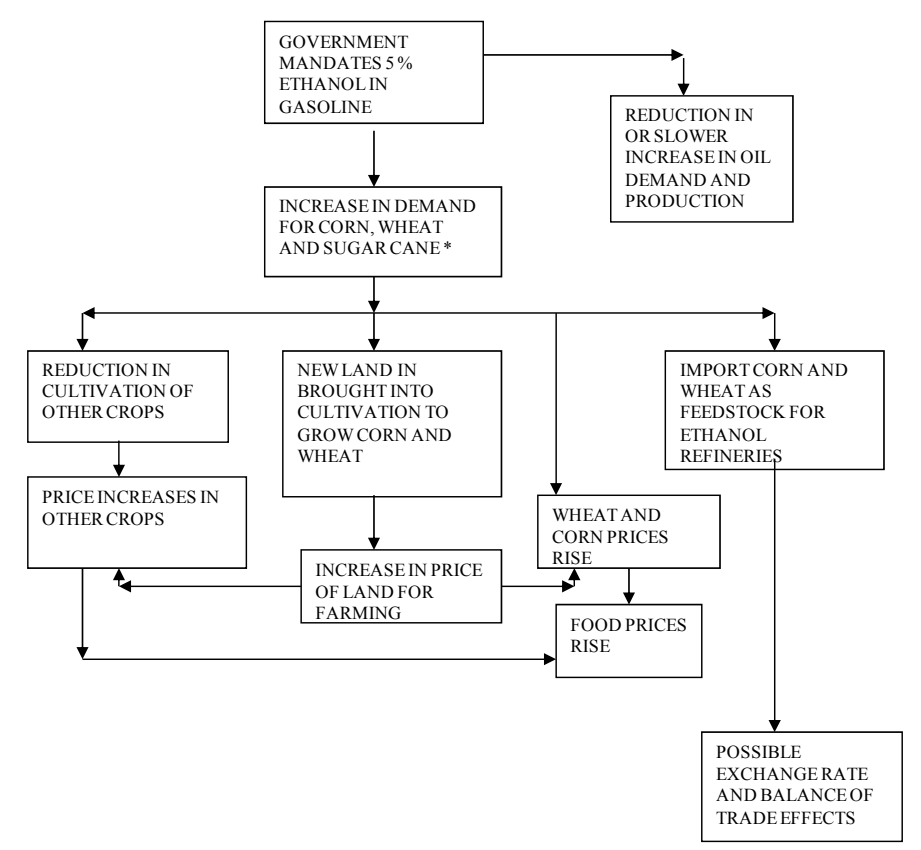

Figure 1. Biofuel production and impact on related markets

* Corn is by far the largest feedstock in the production of ethanol. 
The links between ethanol production/consumption and various sectors of the economy are illustrated in Figure 1.

The most widely discussed issue related to the increased production of ethanol is the impact of ethanol production on the price of corn-based food. In addition to the effect on food prices, it has been argued that ethanol production drives up land values, the price of other agriculture crops, leads to an inefficient resource allocation and an unplanned redistribution of wealth. It was noted above that bio-fuels are heavily subsidized in a number of countries. To the extent that public policy drives the production of ethanol that leads to higher food prices, governments are effectively transferring wealth from consumers to producers of corn and to a lesser extent, wheat and sugar cane. In addition, the massive subsidies to encourage bio-fuel production, mainly ethanol, effectively transfers wealth from consumers as taxpayers to ethanol producers. The link between ethanol production and the price of food also has implications for food supplies around the world.

\section{The Demand for Ethanol and Corn Prices}

On October 13, 2010, the United States Environmental Protection Agency (EPA) waived the regulation that limited the amount of ethanol in vehicle fuel. Allowing the ethanol content of fuel to rise to 15 percent of the total volume of fuel represented a 50 percent increase and it was the first change in the regulation in 32 years (Environmental Protection Agency, 2010). For more than a decade there has been a strong global opposition to the conversion of corn into fuel, an opposition that has pitted livestock/poultry producers against farmers, politician against politician and one government department against another. Lobbying efforts on behalf of ethanol production by the producers of ethanol and growers of corn have intensified in recent years. The announcement quickly fanned the embers of discontent among opponents of ethanol as a fuel.

The announcement by the EPA led to the second spike in corn prices in as many days after the United States Department of Agriculture (USDA) announced that corn output in 2010 would be below expectations. Ethanol producers were in the process of increasing demand for corn in response to the EPA announcement and the USDA news release added to that shift in demand and a significant increase in corn prices. The economics of ethanol demand and corn prices can be explained in the following simplified framework.

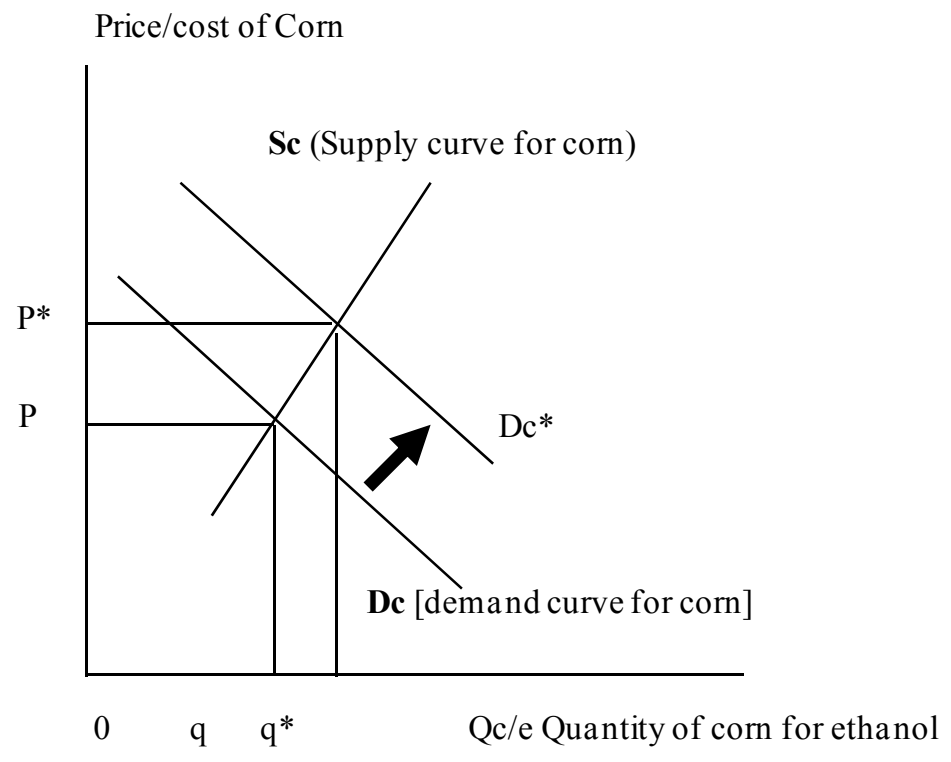

Figure 2. Ethanol demand and the price of corn

The first period demand schedule for corn needed in the ethanol industry is shown as Dc and the short run supply of corn is shown as Sc. The slope of the supply curve simply indicates that more corn is available in the short run but will have to be drawn from other purposes or imported at a higher cost. Dc* illustrates an increase in the demand for corn by the ethanol industry as a result of government directives requiring more ethanol in vehicle fuel. The likely outcome of these decisions raises the price of corn from $\mathrm{P}$ to $\mathrm{P}^{*}$. It has been argued that the increase in the price of corn may be the result of factors other than the increased production of ethanol and no one would dispute that possibility. A poor corn harvest in China or Australia will certainly impact supply in the 
short run. In addition, the simple explanation above is based on what happens in the short run. What if corn yields can be greatly increased? What if more corn is grown in place of other crops? What would be the effect of bringing marginal land or forested land into corn production? These issues are examined below.

There is widespread agreement that the rapid increase in the demand for corn and wheat to fuel ethanol production puts pressure on corn and wheat prices. The empirical debate centers on the degree or extent to which the increase in demand drives up corn prices. A study examining the introduction and growth of ethanol plants in the U.S. between 2001 and 2004 concluded there was a direct impact on ethanol demand and corn prices (McNew \& Duane, 2005). One independent researcher in Canada concluded that $37 \%$ of the rise in corn prices can be attributed to the increased use of corn for ethanol production (Kowal, 2008).

\section{The Demand for Ethanol and the Price of Food}

There are dozens of uses for corn (http://www.ontariocorn.org/classroom/products.html). Of these, thirty-four are direct inputs to processed food, beverages the production of meat and poultry. The link between corn and food has two important components. With no significant change in the cost of other inputs, higher corn and wheat prices will directly increase the cost of bread, mayonnaise, breakfast cereal and beer. Indirectly, high corn [and wheat] prices raise the cost of producing live stock and poultry. For example, researchers at the George Morris Centre in Guelph, Ontario, concluded that given current demands for coTrn by the ethanol industry, the economic cost to the red meat industry could be as high as $\$ 150$ million annually (Mussell, 2008). The economics of this link are quite simple.

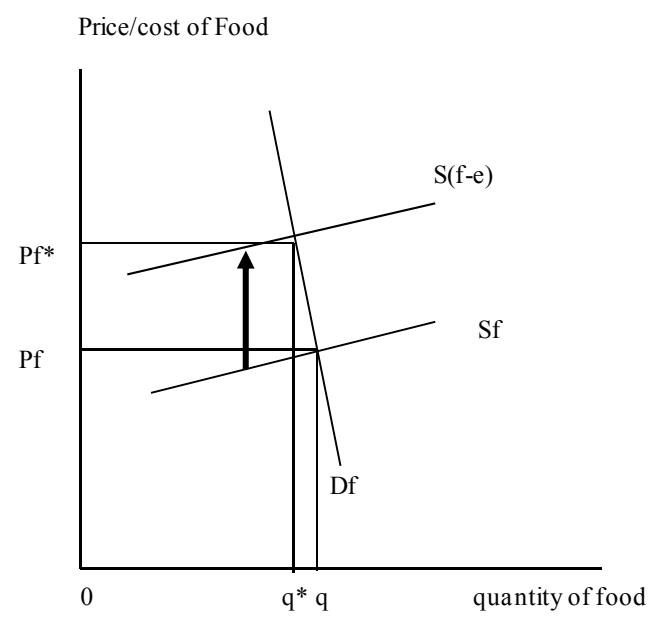

Figure 3. The relationship between corn for ethanol and the supply of food

The initial supply curve for food is Sf and given the demand for food shown as Df, the price of food is Pf. The increase in the demand for corn as a feedstock for ethanol reduces the amount of corn available for food production shifting the supply of food to $\mathrm{S}(\mathrm{f}-\mathrm{e})$. Given that the demand for food is usually considered to be inelastic e.g. price increases do not reduce demand by a significant amount, the price of food rises to $\mathrm{Pf}^{*}$. If corn represents 20 per cent of the total value of inputs to a particular food and if the price of corn increases 25 per cent, the cost of that item of food will rise in the short run by 5 per cent. If the rise in corn prices is the consequence of a significant increase in the demand for corn by ethanol producers, few would argue there is no ethanol demand-food price link.

As one might expect there is controversy around the magnitude of this link. A report from the Organization for Economic Co-operation and Development (OECD) estimated there will be a 20 percent to 50 percent increase in food prices in the next decade, the result of a number of factors including the demand for bio-fuels (OECD, 2007). Another report notes that although the price increase cannot be blamed solely on ethanol demand, its influence cannot be ignored and will contribute to the upward price pressure on food (Doornbosch \& Ronald, 2007). While dismissing the notion that the main culprit in the rapid increase in food prices was the demand for ethanol, the Chair of the US Council of Economic Advisors suggested that the surge in ethanol production had led to an increase in world food prices of 1.2 percent (Lazear, 2008). Extrapolating from the US data and experience, there is further evidence from Canadian research that domestic food prices, on average, are expected 
to rise by 1.1 per cent due to ethanol related policies and incentives (Simla et al., 2007). Research published in 2008 examining the relationship between ethanol and food prices concluded that as far back as 2006, Canadian food costs were approximately $\$ 400$ million higher due to the increase in ethanol production (Auld, 2008). Given the future stream of incentives for ethanol production based on the government mandated blending ratio, the additional cost for food due to ethanol demand is likely to be $\$ 800$ million annually by 2012 . In a Massachusetts Institute of Technology journal, Kevin Bullis recently argued that the link between ethanol demand and food prices is linked directly to U.S. fuel policy (Bullis, 2011). Finally, a report in 2010 by the World Bank suggested that the impact of ethanol on food prices is not as large as originally thought (Govinda \& Ashish, 2010). It is unlikely there will be a definitive answer to the question: what is the precise link between the production of ethanol and food prices? However, the evidence clearly points to an association between the two.

\section{Ethanol Demand and the Impact on Agriculture}

\subsection{The 'Crowding Out' of Corn for Food by Corn for Ethanol}

The reaction of the agriculture sector to an ethanol demand-induced rise in corn prices can be summarized as follows. Assume that the global demand for corn as a feedstock for ethanol production and the demand for corn for food are one in the same. In the absence of any demand for corn from the ethanol industry, the price of corn will be determined by market forces of supply and demand. If a second source of demand is added, [the demand by ethanol producers for corn], there is now a combined demand for corn from the agri-food sector and the ethanol sector. In the short run, this leads to a rise in the price of corn and the possibility of less corn available for food production. The higher cost of corn for all buyers is shifted to consumers, in part, depending on the elasticity of demand and other factors. Over a period of time, the total supply of corn may be augmented due to an increase in corn yield per hectare [perhaps by enhancing fertilizer applications or opening new marginal land to corn production]. The result will take pressure off corn prices for both the ethanol industry and the agriculture sector but in order to stabilize the price of corn, the expansion in the supply must keep pace with the combined increase in demand for corn as a food input and as a ethanol input. A more formal analysis is described in Figure 4.

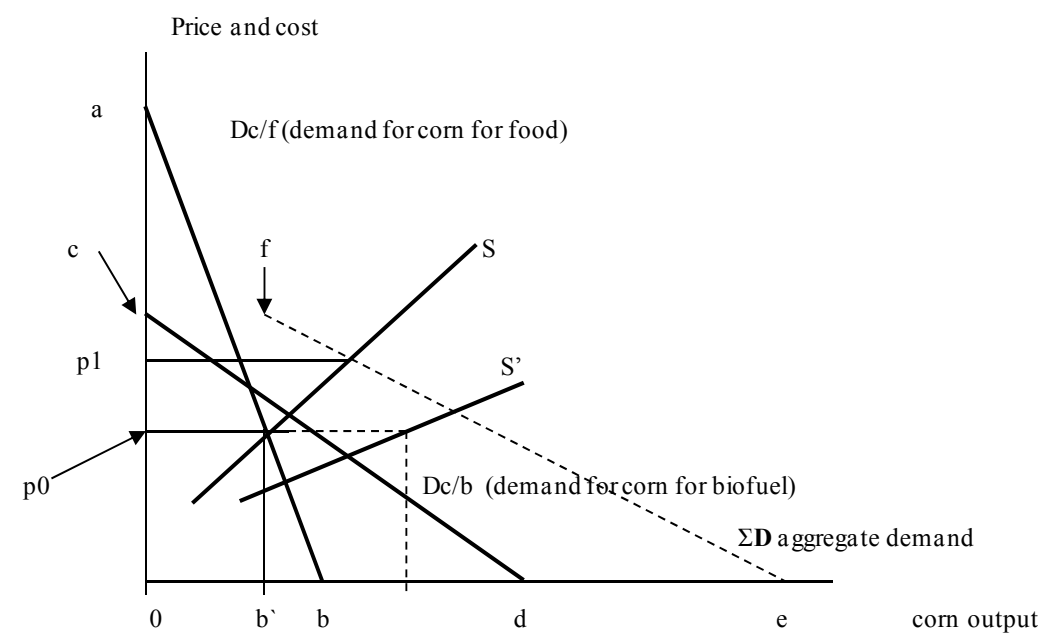

Figure 4. The demand for corn for ethanol and food and the price of food

The demand for corn used to produce food is shown as the line ab. The supply of corn in the short run is shown as SS. The result is a market price of $\mathrm{p} 0$ and quantity of corn sold equal to $0 \mathrm{~b}$. The demand for corn for bio-fuel is introduced as represented as the line cd and together, the total demand is the horizontal addition of the two demand schedules or afe. This increase in demand driven by the demand for corn by ethanol producers results in a short run price rise for corn to p1 where SS intersects the line afe. There are now two sources of demand competing for the corn output and as a result, the price of corn rises and the corn for food is reduced slightly. If more land is brought into corn production or corn yields were increased, the supply of corn would increase to $\mathrm{S}$ 'S' and the price would fall back to $\mathrm{p} 0$ and the demand for corn for food could be satisfied as it was in the pre bio-fuel era while bio-fuel would acquire 100 per cent of the increase in corn production. A similar type of analysis could be undertaken to demonstrate that, if corn growing were substituted for perhaps growing oats or 
rye or beans, the supply of these crops would decline and their prices would likely rise. To the extent these crops inputs to food production, the rise in the price of food is precipitated not by the price of corn in this instance but the cost of other inputs. Can corn production (and thus supply) match the increase in demand due to ethanol production?

\subsection{Can the Supply of Corn Meet the Aggregate Demand?}

The evidence up to 2007 pointed to the inability of corn output to match the increase in demand and stabilize prices (Forge, 2007). In the United States, the consensus at the end of 2011 suggests that the increase demand for corn by the ethanol industry would mean a reduction in U.S. corn exports and food aid. The implementation of the new blending rules in the U.S. in 2011 allowing a greater ethanol content in vehicle fuel created one of the tightest supply situations in years. Higher gasoline prices make ethanol more competitive and retailers may exceed the mandated blending ratios where possible. Ethanol output was up more than 20 percent in 2010 compared to 2009. However, ethanol output declined in 2011 in part because of poorer than expected harvests and the inability to access stocks of corn destined for export. In the longer run, increases in supply will be insufficient to stabilize agriculture prices unless the U.S. reduces drastically corn exports or imports ethanol from abroad.

The supply of corn could, conceivably, be augmented by expanding the acreage for corn growing. Is there sufficient arable land to expand corn production to meet food and fuel needs? The OECD estimates that to replace 10 percent of transportation fuel with ethanol, Canada and the EU would have to devote between 30 percent and 70 percent of current crop areas to ethanol feedstock production (OECD, 2006). Looking at the challenge from another perspective, in 2006, there were 2.77 million acres of land in Canada devoted to corn production. One year later, this had risen to 3.5 million acres (Teneycke, 2007) and it has been estimated that to reach Canada's bio-fuel target of 5 percent of total fuel consumption, approximately one-half of the current farmland used for corn will be required (Forge, 2007). Similar forecasts have been made for the United States. Some of the pressure on expanding corn acreage could be offset by substituting more wheat as a feedstock for ethanol than is currently used. This is not a panacea for the challenge posed by higher food prices: more demand for wheat will put pressure on wheat prices and the cost of wheat based foods.

\subsection{What Does the Empirical Research Reveal about Ethanol and Food Prices?}

It would not be an understatement to suggest that there have been at least a thousand studies, reports, chapters in books and academic journal articles on the relationship between ethanol demand and agriculture markets. Conclusions have been drawn from as diverse sources as casual observations of ethanol production and corn prices to sophisticated multi market econometric studies. The fundamental economics as we have seen above are rather simple involving demand, supply and prices. Few dispute these simple economics. The longer run analysis is much more complicated and modeling the impact of ethanol mandates on agriculture and food prices to take account of the multi market interactions has led to the conclusion in one study that in the long run the price effect, that is the increased demand for ethanol on corn and wheat prices, may not be severe given certain assumption (Zhang et al., 2009). The researchers concluded that recent agricultural price increases may have been caused by the rapid increase in ethanol production but the price increases are likely transitory. There was one important caveat to the findings: agricultural price increases as a result of an ethanol demand shift may persist if land is taken out of production for food inputs and used for ethanol. This is an important caveat. If there is widespread belief that ethanol demand will lead to an increase in corn prices and those higher prices convince growers to convert land currently dedicated to other products into corn production, there will be a shortage of those crops leading to higher prices and an increase cost of food.

The work of Professor Ujjayant Chakravorty and his colleagues also suggests that in the longer run, the impact of the bio fuel mandates in the U.S. and Europe Union (EU) will not have a major impact on food prices (Chakravotry et al., 2010). Their work is important because it examines the U.S. and EU mandate in the context of global economic inter-relationships and the collective impact of first and second generation bio fuels. Their results depend on several key relationships and assumptions. First, it is assumed that the global price of crude oil will rise steadily in the years ahead. However, if the proven reserves of oil increase beyond what is expected or changes in technology lead to less expensive methods to extract shale or tar sands oil, the real price of oil may rise more slowly than expected. Second, the model fixes the supply of land for cultivation in the short run. Third, second generation bio-fuels will slowly replace first generation bio-fuels reducing corn and wheat as a feedstock for biofuels. This is somewhat restrictive. There is considerable interest and money invested in cellulosic ethanol utilizing non food crops that will require large tracts of land which could have an impact on the pattern of agriculture. 
In the model, the need in the U.S. to use land for corn because of the immediate mandate for ethanol production results in a reduction in U.S. exports of corn leading to more food being produced in middle and lower income countries at a higher cost. However, as second generation bio-fuels become more important [requiring little or no land], the land that had been cultivated to grow corn for ethanol reverts back to producing corn for food. This leads to a corresponding increases in food exports and less pressure on the conversion of marginal land in developing countries into food production: food price increases are dampened (Note 1). In addition, the model argues that with rising incomes, there will be a shift in middle and lower income countries to more meat than vegetables leading to higher land rents and higher prices of crops. The general results of this model show food prices rising even without a bio-fuel mandate and the bio-fuel mandate adding only a small additional increase in prices. A critical assumption leading to the dampening of ethanol demand on food prices is the robustness of second-generation bio-fuel production and consumption. Results to date suggest this may be years into the future.

Other research suggests that the ethanol-food price link is stronger. The United Nations World Food Program notes that it is increasingly difficult to provide food aid to poor nations because land has been diverted away from growing food to the much more lucrative activity of growing corn as a feedstock to produce ethanol (Blas \& Jenny, 2007). As cropland is diverted from corn-for-food to corn-for-fuel, the quantity of corn available for export will drop and the price will rise. There may be a windfall gain from the price rise to subsistence farmers in less-developed countries who will profit from higher corn prices, perhaps providing them with a source of capital for improvements to agricultural productivity. If, however, they also switch to crops-for-ethanol production, the food shortage will be accentuated. The impact on land is not trivial. A doubling or tripling of corn or wheat prices can lead to a significant rise in the value of arable land, resulting in a windfall for owners of agricultural land, but not necessarily for the farmers or farm workers.

Increasingly, it is argued that governments should steer ethanol producers away from corn and wheat into cellulosic ethanol as a means of taking pressure off food prices. At this point in time, that would be a very expensive proposition since it would require a major increase in government subsidies to produce cellulosic ethanol in the commercial quantities needed to meet the current ethanol targets without a significant increase in the price of fuel. If non-food crops were used for cellulosic ethanol, cultivation could occur on marginal land. However, to limit the cost of production of cellulosic ethanol, there would be an incentive to grow such crops on high0-yield land; the same land used to grow corn or wheat.

\section{Ethanol and Global Food Supplies}

The implementation of ethanol targets in the United States and elsewhere was undertaken with little thought as to the impact that the higher demand for corn would have on the most vulnerable people on the globe: those who rely on food donations to prevent starvation and malnutrition. This tragedy is not simply a matter of U.S. foreign aid to low income countries and countries facing drought and disease: the U.S. is directly affected. It has been estimated that in 2009, the high price of corn, spurred in part by the rising use of ethanol, could cost the U.S. government $\$ 900$ million more in food stamps and child nutrition programs (Congressional Budget Office, 2009). A rise in grain prices, especially corn, has a negative effect not only at home but on U.S. foreign aid programs. In 2007, the United States, the world's dominant food donor, purchased less than half the amount of food aid this year than it did in 2000, according to recent data from the Department of Agriculture. The budget for food aid has simply not kept up with the price of corn and other grains needed to feed millions around the world (Westcott, 2007). The FAO, in its forecast of food demand and supply, clearly identified the negative impact that ethanol policy will have on food supplies and prices (www.oecd.org/dataoecd/43/6/43256458.pdf). A lack of food aid from the U.S. and to a lesser extent Canada, Europe and Australia, is compounded by the incentive for farmers in low income countries to grow corn-for fuel rather than corn to supplement local food supplies. The United Nations World Food Program noted that it is increasingly difficult to provide food aid to poorer nations because land has been diverted from food to much more lucrative ethanol feedstock production (Blas).

The debate in the last five years surrounding the link between ethanol demand and production and food prices has created a wide range of estimates of the linkage. However, very few dispute that there is some effect. After all, since 2007, when the U.S. established ethanol mandates, 200 ethanol refineries have gone into production and in 2010 will produce 12.8 billion gallons of ethanol using almost 5 billion bushels of corn, an increase of 250 million bushels over the previous year. Between 2006 and 2008, the amount of corn used in U.S. ethanol distilleries increased by 41 million tons and coincided with a tripling of key grain prices worldwide (Brown, 2009). It is difficult to argue that ethanol demand has little to do with corn prices and, by extension, food prices. The 2009 figures from the U.S. Department of Agriculture show that one quarter of U.S. grain crops are used to 
produce ethanol as a vehicle fuel. To place this in perspective, this amount of corn would feed 330 million people.

\section{Summary}

The rapid development of ethanol impacts agriculture and food markets and the effects are complicated and far reaching (Dermot et al., 2009). The extent to which the rise in corn prices is driven by ethanol production affects the livestock and poultry industry and a variety of food products. The long term effects may not be a severe as once thought but the result of forecasting models depend on optimistic assumptions that may not emerge. The diversion of cropland from corn and wheat for food to crops for fuel will contribute to changes in the pattern of exports and imports of these commodities and will likely affect the distribution and prices of food world-wide.

\section{References}

Auld, D. (2008). The Ethanol Trap, CD Howe Institute, Toronto.

Blas, J. op.cit.

Blas, J., \& Jenny, W. (2007). UN Warns It Cannot Afford to Feed the World, Financial Times, July 16.

Brown, L. (2009). Plan B 4.0: Mobilizing to Save Civilization. N.Y.:W.W. Norton and Company.

Bullis, K. (2011). Ethanol Blamed for Record Food Prices. Technology Review, March 23.

Chakravotry, U., Hubert, M. H., Moreaux, M., \& Nostbakken, L. (2010). Will Biofuel Mandates Raise Food Prices? Congressional Budget Office. (2009). The Impact of Ethanol Use on Food Prices and Green House Gas Emissions. Congress of the United States, Washington, D.C. April.

CREE Conference, October, University of Guelph, Guelph, Ontario.

Dermot, J. H., Bruce, A. B., Jacinto, F. F., Simla, T., Amani, E., Tun-Hsiang, Y., ... Jerome, D. (2009). Biofuels: Potential Production Capacity, Effects on Grain and Livestock Sectors, and Implications for Food Prices and Consumers. Working Paper 09-WP 487, Center for Agriculture and Rural Development, Iowa State University, Ames, Iowa.

Doornbosch, R., \& Ronald, S. (2007). Biofuels: Is the Curse Worse Than the Disease, Paris OECD, September.

Environmental Protection Agency. (2010). EPA Grants E15 Waiver for Newer Vehicles/A new label for E15 is being proposed to help ensure consumers use the correct fuel, October 13, United States, Washington.

Forge, F. (2007). op.cit

Forge, F. (2007). Biofuels-An Energy, Environmental or Agriculture Policy? Ottawa, Science and Technology Division, Library of Parliament.

Govinda, T., \& Ashish, S. (2010). Biofuels:markets,targets and impacts. World Bank, Washington, D.C. July, 2010.

Kowal, A. (2008). VAR Analysis of United States Corn Prices between 1986 and 2008. MA Thesis, University of Guelph, Ontario.

Lazear, E. (2008). Testimony of Edward P. Lazear, Chairman, Council of Economic Advisors, Senate Foreign Relations Committee, United States, May 14.

McNew, K., \& Duane, G. (2005). Measuring the Impact of Ethanol Plants on Local Grain Prices. Review of Agricultural Economics, 27(2), 164-180. http://dx.doi.org/10.1111/j.1467-9353.2005.00219.x

Mussell, A. (2008). Ethanol, Red Meat Trade and Food Security. George Morris Centre, Guelph, Ontario.

OECD. (2006). Agricultural Market Impacts of Future Growth in the Production of Biofuels. Working Party on Agricultural Policies and Markets, Paris, Feb. 2006

Organization for Economic Cooperation and Development (OECD). (2007). OECD-FAO Agriculture Outlook, 2007-2016, Paris.

Simla, T., Amani, E., Jacinto, F. F., Dermot, J.H., Bruce, A. B., Tun-Hsiang, Y., ... John, C. B. (2007). Emerging Biofuels: Outlook of Effects on US Grain, Oilseed and Livestock markets, Centre for Agricultural and Rural Development, Iowa State University, Report 07-SR 101.

Teneycke, K. (2007). Canada's Emerging Renewable Fuels Industry. Presentation to Railway Association of Canada Ethanol Conference, Mississauga, Ontario, April 26.

Westcott, P. (2007). Ethanol Expansion in the United States, Outlook, USDA, May. 
Zhang, Z. B., Luanne, L., Cesar, E., \& Michael, W. (2009). Ethanol, Corn, and Soybean Price Relations in a Volatile Vehicle-Fuels Market. Energies, 2, 320-339. http://dx.doi.org/10.3390/en20200320

http://www.ontariocorn.org/classroom/products.html

www.oecd.org/dataoecd/43/6/43256458.pdf

\section{Note}

Note 1. Second generation bio-fuels likes cellulosic ethanol can be manufactured with lignocellulosic waste material such as timber slash, corn stover and recycled wood waste. Other cellulose ethanol processes utilize non-food crops such as switch grass which do place demands on land use. 